\title{
Intestinal hookworm infestation causing chronic anaemia
}

\author{
Marcello Cintolo, Lorenzo Dioscoridi, Mutaz Massad, Massimiliano Mutignani
}

Digestive and Interventional Endoscopy Unit, Azienda Socio Sanitaria Territoriale Grande Ospedale Metropolitano Niguarda, Milano, Italy

\section{Correspondence to}

Dr Lorenzo Dioscoridi, dioscoridi.lorenzo@virgilio.it

Accepted 18 December 2018

\section{DESCRIPTION}

This image (figure 1) is a photogram of a smallbowel capsule endoscopy and shows an intestinal Taenia spp causing persistent anaemia (requiring several blood transfusions) due to many jejunal and

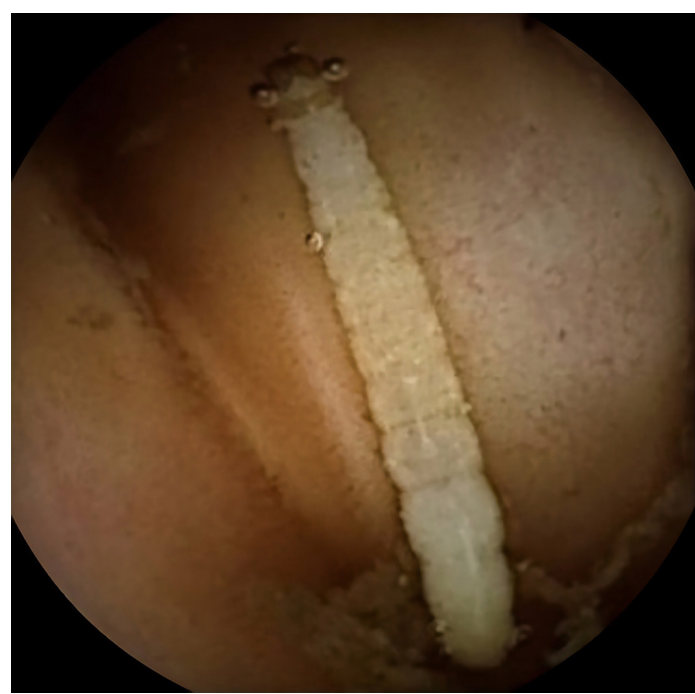

Figure 1 The intestinal wo $\mathrm{rm}$ seen at 11 hours $07 \mathrm{~min}$ during the capsule endoscopy.

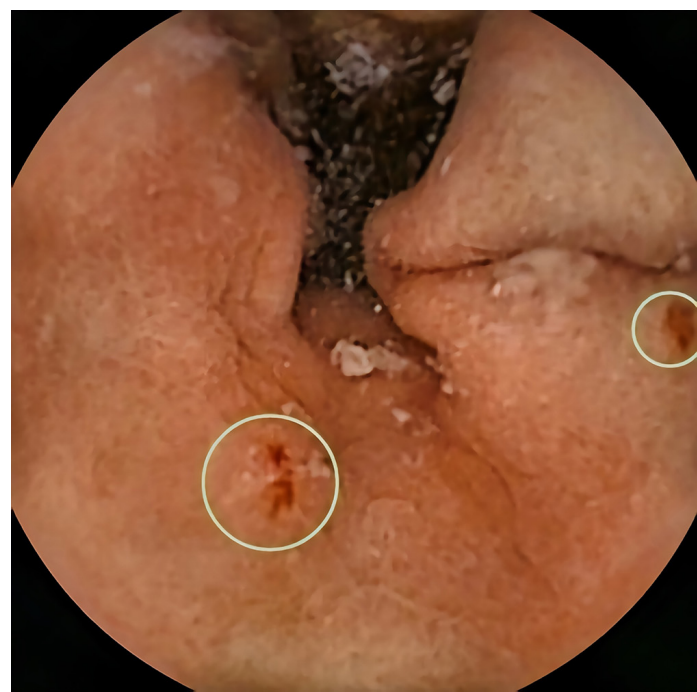

Figure 2 Mucosal multiple erosions caused by the intestinal wo rm. ileal mucosal erosions (figure 2) in a 52-year-old patient under oral anticoagulant therapy. Both a previous oesophagogastroduodenoscopy and colonoscopy were negative for any bleeding source. Subsequent capsule endoscopy was performed to investigate this occult blood loss. ${ }^{12}$ The examination showed many mucosal erosions of the smal bowel and a flat, segmented intestinal worm recognisable as a Taenia spp. After an adequate antiparasitic therapy, the patient reported no more anaemia. This is a rare finding during capsule endoscopy and was not evidenced by the analysing system. Our case is in line with the reported cases in the available literature about intestinal worms' finding during capsule endoscopy. ${ }^{12}$

\section{Patient's perspective}

I would like to thank you all the Endoscopy Team of Niguarda Hospital. My life was ruined by this chronic anaemia. I felt sick for all these months. Now, after few days of oral medications, I returned to life!

\section{Learning points}

- View and study all capsule endoscopy examination, especially if the 'main photograms' are not diagnostic.

- Think also about the rare cases of anaemia especially in case of occult blood loss.

Contributors MC studied the examination and found the intestinal warm. MMa revised the manuscript and the figures. LD prepared the manuscript. MMu revised the manuscript.

Funding The authors have not declared a specific grant for this research from any funding agency in the public, commercial or not-for-profit sectors.

Competing interests None declared.

Patient consent Obtained.

Provenance and peer review Not commissioned; externally peer reviewed.

\section{REFERENCES}

1 Wei KY, Yan Q, Tang B, et al. Hookworm infection: a neglected cause of overt obscure gastrointestinal bleeding. Korean J Parasitol 2017;55:391-8

2 Galán-Puchades MT, Fuentes MV. Parasites \& Health Research Group On the visual diagnosis of human taeniasis by capsule endoscopy. Clin Gastroenterol Hepatol 2018;16:1177-8. 
Copyright 2018 BMJ Publishing Group. All rights reserved. For permission to reuse any of this content visit https://www.bmj.com/company/products-services/rights-and-licensing/permissions/

BMJ Case Report Fellows may re-use this article for personal use and teaching without any further permission.

Become a Fellow of BMJ Case Reports today and you can:

- Submit as many cases as you like

- Enjoy fast sympathetic peer review and rapid publication of accepted articles

Access all the published articles

- Re-use any of the published material for personal use and teaching without further permission

For information on Institutional Fellowships contact consortiasales@bmjgroup.com

Visit casereports.bmj.com for more articles like this and to become a Fellow 